\title{
The feeding activity of Colossoma macropomum larvae (tambaqui) in fishponds with water hyacinth (Eichhornia crassipes) fertilizer
}

\author{
Sipaúba-Tavares, LH. ${ }^{\text {a* }}$ and Braga, FMS. ${ }^{\text {b }}$ \\ aLaboratório de Limnologia e Produção de Plâncton, Centro de Aqüicultura, Universidade Estadual Paulista - UNESP, \\ Via de Acesso Prof. Paulo Donato Castellane, s/n, CEP 14884-900, Jaboticabal, SP, Brazil

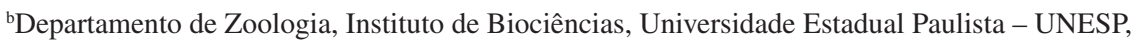 \\ CEP 13506-900, Rio Claro, SP, Brazil \\ *e-mail: sipauba@ caunesp.unesp.br
}

Received August 22, 2005 - Accepted December 13, 2005 - Distributed August 31, 2007

(With 1 figure)

\begin{abstract}
Analysis of macrophyte water hyacinth (Eichhornia crassipes) as an organic fertilizer of Colossoma macropomum (tambaqui) larvae in ponds is provided. Water hyacinth produce an organic fertilizer at the ratio of $100 \mathrm{~g} \cdot \mathrm{m}^{-2}$ in tambaqui ponds. Two groups of 5,000 larvae were transferred to two fishponds with and without water hyacinth fertilizer and reared until day 43 . The fertilized pond evidenced more plankton abundance during the entire production period when compared with the control pond $(\mathrm{P}<0.001)$. The phytoplankton community in the pond was not significantly different than in gut contents $(\mathrm{P}>0.05)$ in both ponds (with and without organic fertilizer). Fish larvae failed to show any preference or selectivity in relation to the different algae $(\mathrm{P}>0.01)$ in the pond, but exhibited high ingestion selectivity for zooplankton $(\mathrm{P}<0.05)$. Application of fertilizer increased $(\mathrm{P}<0.05)$ the abundance of phytoplankton and zooplankton in the treatment pond. Since water hyacinth fertilizer is quite cheap and easily available, it may be conveniently used to enhance fish yield in ponds.
\end{abstract}

Keywords: larvae feeding, water hyacinth fertilizer, ponds, plankton.

\section{Atividade alimentar de larvas de Colossoma macropomum (tambaqui) em viveiro fertilizado com aguapé (Eichhornia crassipes)}

\begin{abstract}
Resumo
O objetivo deste trabalho foi avaliar a influência do aguapé como fertilizante orgânico no comportamento alimentar de larvas de tambaqui (Colossoma macropomum) em viveiros de larvicultura. O aguapé foi utilizado para produzir um fertilizante orgânico na proporção de $100 \mathrm{~g} . \mathrm{m}^{-2}$. Dois grupos de 5.000 larvas foram transferidos para dois viveiros com e sem fertilizante de macrófita e criados durante um período de 43 dias. O viveiro contendo fertilizante de macrófita apresentou maior abundância de plâncton durante o período de estudo quando comparado ao viveiro controle $(\mathrm{P}<0,001)$. A estrutura da comunidade fitoplanctônica não apresentou diferença significativa daquela encontrada no trato digestivo $(\mathrm{P}>0,05)$ e nos viveiros (com e sem fertilizante), evidenciando que as larvas de peixe não apresentaram preferência ou seletividade $(\mathrm{P}>0,01)$ em relação às diferentes algas presentes no viveiro, somente em relação aos organismos zooplanctônicos $(\mathrm{P}<0,05)$. A aplicação de fertilizante aumentou significativamente $(\mathrm{P}<0,05)$ a abundância de fitoplâncton e zooplâncton nos viveiros estudados. O fertilizante de aguapé é fácil de ser obtido e é barato, assim poderá ser utilizado como uma nova alternativa para melhorar a produção dos viveiros de piscicultura.
\end{abstract}

Palavras-chave: alimentação de larva, fertilizante com aguapé, viveiros, plâncton.

\section{Introduction}

Several research projects have shown that some vascular aquatic plants are capable of absorbing metals, organic and inorganic substances through their roots. Since aquatic plants absorb part of the phosphorus and nitrogen released in ponds and fish tanks in order to grow, they partially reduce the discharge of these nutrients in the system (Jorgensen, 1994; Polprasert and
Khatiwada, 1998; Saha and Jana, 2002; Das and Jana, 2004).

Water hyacinth (Eichhornia crassipes) is a wild freshwater plant belonging to the Pontederiaceae family, native to South America, but naturalized in many tropical and subtropical regions of the world. It grows and reproduces (by seeds and by daughter plants) at very high 
rates, yielding up to $100-400 \mathrm{mt} \cdot \mathrm{ha}^{-1} \cdot$ year $^{-1}$ (El-Sayed, 2003).

Water hyacinth contains an appreciable quantity of nitrogen, phosphorus, magnesium, sulfur, manganese, copper, zinc, and other compounds. Although it may be richer in iron, calcium and potassium than terrestrial plants, its commercial use has not been fully exploited because of its low level of dry matter (Sahu et al., 2002).

As a primary producer, water hyacinth takes from the water the essential nutrients for its growth. Perhaps this is the reason for the great number of ecological niches and great diversity of species (plankton, insects, bacteria and others) found close to, or associated with, the macrophyte roots.

The organic matter retained by these aquatic plants consists of particles that may be directly utilized as food by the macro-fauna associated to these plants, with a rapid return to the trophic chain. Therefore, it is highly interesting to evaluate the use of these plants, which, even after drying, still have nutrition value, and thus may become a low cost and potentially feasible organic fertilizer.

Current research evaluated the effects of water hyacinth (Eichhornia crassipes) as an organic fertilizer for tambaqui larvae (Colossoma macropomum) in ponds and its influence on the planktonic community.

In Brazil, there is scanty information on the feeding preference of tambaqui larvae in fishponds. Tambaqui is a tropical freshwater fish from the Amazonian basin with high aquaculture potential when compared to other native species. Endurance in handling, low dissolved oxygen concentration and high fertility rate are the main characteristics that make Colossoma macropomum suitable for culture (Sá, 1989).

\section{Materials and Methods}

\subsection{Site and fish larvae}

The tambaqui larvae originated from the brood stock kept at CEMIG (Centrais Elétricas de Minas Gerais), and the experiment carried out at the Aquaculture Center of the Universidade Estadual Paulista (UNESP) in Jaboticabal SP Brazil ( $21^{\circ} 15^{\prime} \mathrm{S}$ and $\left.48^{\circ} 18^{\prime} \mathrm{W}\right)$. Two groups of 5,000 larvae transferred to two fishponds $\left(50 \mathrm{~m}^{2}\right)$, one with water hyacinth fertilizer (WFP) and the other without water hyacinth fertilizer (WIFP), were reared until day 43. Continuous water flow provided a $5 \%$ daily exchange rate of its volume. Eight-day-old tambaqui larvae (Colossoma macropomum) were fed a supplementary diet containing $40 \%$ crude protein, three times daily, at $1 \%$ average live weight rate.

\subsection{Water hyacinth fertilizer}

Water hyacinth (Eichhornia crassipes) was harvested manually from the Aquaculture Center wetland to produce an organic fertilizer with an application rate of 100 g.m $\mathrm{m}^{-2}$. Leaves, leaf stalks and roots were sun-dried until their water content dropped to approximately $50 \%$. About $5 \mathrm{~kg}$ of Eichhornia crassipes was dried at $60{ }^{\circ} \mathrm{C}$ for 24 hours, finely ground and stored in labeled plastic bags until use. It was later boiled in $2.5 \mathrm{~L}$ distilled water for an hour, and the hot extract was filtered and the supernatant utilized as organic fertilizer. Fertilizer was applied entirely over the dry pond bottom before stocking the pond with fish larvae. The control pond received no fertilizer. So that fertilizer could be absorbed by the bottom soil, no water was introduced in the pond for the 72 hours following the application. After this period the pond was filled to mid-capacity and kept at that level for 48 hours. After this preparation period the pond was completely filled and continuous water which was allowed to flow through the pond during the entire 43-day production period. Table 1 shows nutrients content in the water hyacinth fertilizer.

\subsection{Tambaqui larvae growth}

Ten tambaqui larvae were selected for measurement. Weight and length of tambaqui larvae were taken on days $8,15,22,29,36$ and 43 . Whereas length was taken to the nearest $\mathrm{mm}$ under a dissecting microscope, weight was measured on a $0.1 \mathrm{mg}$ precision scale.

\subsection{Feeding activity}

During the 43-day period, larvae were caught weekly $(8,15,22,36$, and 43-day-old) at 9:00 A.M. with a $58 \mu \mathrm{m}$ mesh hand net. The larvae were anesthetized with benzocaine solution $\left(0.3\right.$ g.L $\left.\mathrm{L}^{-1}\right)$ for 10 minutes in order to avoid regurgitation and then fixed in $10 \%$ formalin.

Food contents of the whole gut were analyzed quantitatively and qualitatively for their ingested material. Only entirely and partially digested identifiable food items were analyzed and all determinations were done in triplicate.

\subsection{Statistical analysis}

Spearman rank correlation coefficient analysis, applied to fish feeding (Siegel, 1975) was employed to study correlation between items available in both ponds (with and without water hyacinth fertilizer). Instantaneous growth rate $(G)$ was estimated by the variation of weight and length with time, in days (Ricker,

Table 1. Nutrient contents in water hyacinths fertilizer.

\begin{tabular}{lc}
\hline \multicolumn{1}{c}{ Components } & mg. $\mathbf{L}^{-\mathbf{1}}$ \\
\hline Nitrogen & 95.0 \\
Phosphorus & 91.0 \\
Carbon & 199.0 \\
Manganese & 60.0 \\
Magnesium & 3.9 \\
Iron & $2,127.5$ \\
Potassium & 56.0 \\
Calcium & 1.7 \\
Copper & 0.05 \\
\hline
\end{tabular}


1979). Instantaneous growth rates estimated in the period and in the ponds with and without water hyacinth fertilizer were tested according to the Mann-Whitney test (Siegel, 1975).

\section{Results}

\subsection{Plankton in fish pond}

Higher abundance of Cyanobacteria was reported in WFP or rather, $91.7 \%$ of the total observed individuals, represented mainly by Anabaena flosaquae. In the control pond (WIFP) Cyanobacteria represented $16.09 \%$ of the total individuals. Chlorophyta was more abundant $54.28 \%$, mainly Golenkinia sp. followed by Euglenophyta (28.30\%), and Chrysophyta (1.33\%) of the total algae measured (Table 2; Figure 1).

Table 2. Results of Spearman class correlation test between abundance (individuals. $\mathrm{m}^{-3}$ ) of phytoplankton and zooplankton components, in the fishponds and gut contents for the two treatments, with (WFP) and without (WIFP) water hyacinth fertilizer.

\begin{tabular}{llll}
\hline \multicolumn{1}{c}{ Treatments } & $\mathrm{r}_{\mathrm{s}}$ & $\mathbf{t}$ & $\mathbf{C}$ \\
\hline WFP & & & \\
$\quad$ Phytoplankton & 0.45 & 4.22 & $* *$ \\
$\quad$ Zooplankton & 0.011 & 0.41 & $\mathrm{~ns}$ \\
WIFP & & & \\
$\quad$ Phytoplankton & 0.305 & 2.35 & $*$ \\
$\quad$ Zooplankton & 0.012 & 0.09 & $\mathrm{~ns}$ \\
\hline
\end{tabular}

$\mathrm{r}_{\mathrm{s}}=$ Spearman class correlation; $\mathrm{t}=\mathrm{t}$ statistic;

$\mathrm{C}=$ correlation: $*=\mathrm{P}<0.05 ; * *=\mathrm{P}<0.01$; ns $=$ no correlation, $\mathrm{P}>0.05$.

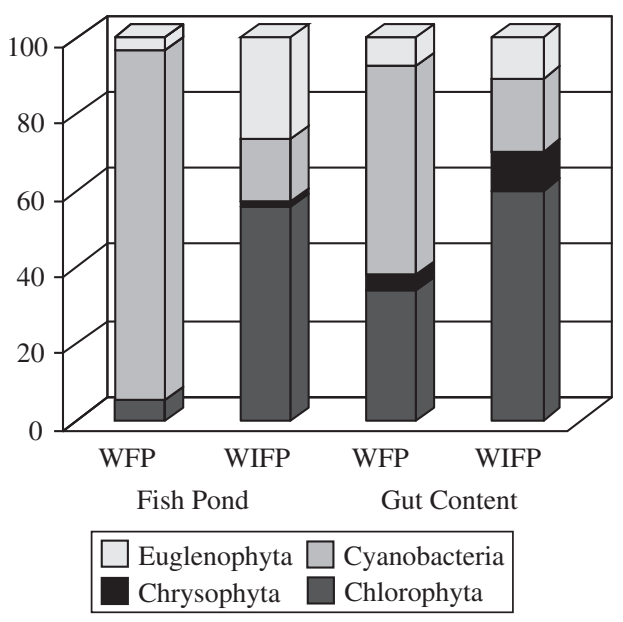

A higher number of phytoplanktonic species (66) and a higher abundance of phytoplankton $\left(9 \times 10^{6}\right.$ individuals. $\left.\mathrm{m}^{-3}\right)$ were reported in WFP when compared with WIFP with a total of 47 species and $2 \times 10^{6}$ individuals. $\mathrm{m}^{-3}$.

The diversity of phytoplanktonic species for the two treatments, with and without water hyacinty fertilizer, was different $(\mathrm{P}<0.01)$. Although the number of species was higher (66) in WFP, its diversity was lower (0.61), owing to low equitability value $(0.15)$ from the non-similarity of the species abundance. The number of species was lower (47) in WIFP and its diversity was higher (2.65) due to higher equitability (0.68). Or rather, there was a more equalized distribution of individuals among the species (Table 2).

The diversity of zooplanktonics species was different in treatments WFP and WIFP $(\mathrm{P}<0.001)$. Number of species (39) and diversity (1.45) in WIFP were higher while equitability was moderate (0.39). In WFP species diversity was lower, namely 1.17 , but abundance was higher $\left(9 \times 10^{6}\right.$ individuals. $\left.\mathrm{m}^{-3}\right)$ when compared with that of the WIFP pond with $2 \times 10^{6}$ individuals. $\mathrm{m}^{-3}$ (Table 2).

Rotifera was the dominant zooplankton in the two ponds, with $86.55 \%$ for WIFP and $93.47 \%$ for WFP of total individuals, followed by Copepoda with 7.98 and $3.58 \%$; Protozoa with 5.60 and $0.76 \%$ and Cladocera with 0.13 and $0.17 \%$, respectively. On the other hand, Rotifera presented the highest number of species of the zooplankton groups with 31 species in the WIFP pond and 23 species in the WFP, mainly Keratella cochlearis, K. lensi, Polyarthra sp., and Proales doliaris (Figure 1).

Cladocera was represented mainly by Diaphanosoma birgei in both ponds. Moina micrura and Daphnia gessneri respectively, totaling 231 and 1,050 individuals. $\mathrm{m}^{-3}$ reported only in the WIFP pond.

Copepoda was represented by two species Argyrodiaptomus furcatus and Thermocyclops decipiens. Calanoida-Copepoda A. furcatus nauplii had a higher rep-

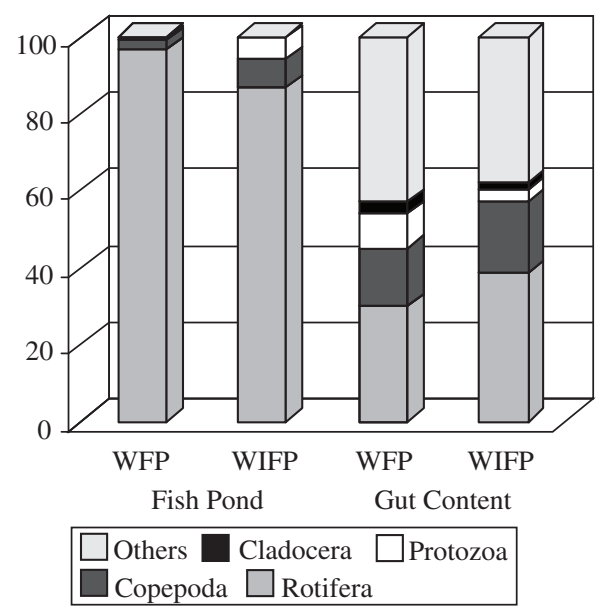

Figure 1. Percentage abundance and composition of different planktonic groups found in the fishponds and gut contents of tambaqui larvae (Colossoma macropomum), in treatments WFP (with fertilizer) and WIFP (without fertilizer), where: others = Chaoborus sp., Insecta, Ostracoda, resting eggs and inorganic particles. 
resentation with 198,661 individuals. $\mathrm{m}^{-3}$ and 171,681 individuals. $\mathrm{m}^{-3}$ in WIFP and WFP ponds, respectively.

Protozoa with four species and with predominance of Arcella discoides, had 42,672 and 150,266 individuals. $\mathrm{m}^{-3}$ in WIFP and WFP ponds, respectively.

\subsection{Feeding activity}

Analysis indicated only a preference for zooplankton species $(\mathrm{P}<0.05)$ and no preference of $C$. macropomum larvae for phytoplankton $(\mathrm{P}>0.01)$. However, a high ingestion of algae, above $80 \%$ of the total gut contents $(\mathrm{P}<0.05)$, occurred. This high ingestion was associated with the availability of phytoplankton in the environment, mainly Chlorophyta, which represented more than $60 \%$ of the total gut contents $(\mathrm{P}<0.05)$ in WIFP treatment (Table 3; Figure 1).

Cyanobacteria found in the gut content were represented mainly by Microcystis sp. with approximately 62.42 and $12.91 \%$ in WIFP and WFP, respectively (Table 3; Figure 1).

Euglenophyta and Chrysophyta algae in gut contents were associated with availability in water ponds $(\mathrm{P}<0.05)$ (Tables 2 and 3).

Although Rotifera represented 29\% of total individuals in gut content, Argyrodiaptomus furcatus nauplii were the most ingested among Copepoda, which demonstrated a positive selection for the organism (Table 4, Figure 1).

Cladocera predominantly Echinischia paulineis and Moina micrura represented 1.75 to $2.72 \%$ of total zooplankton in gut contents. Although the species Diaphanosoma birgei was abundant in the environment, its ingestion was scarce $(\mathrm{P}<0.05)$ (Table 4, Figure 1).

Whereas, as a rule tambaqui larvae feed on Protozoa, Ostracoda, insects, and Chaoborus sp., from day 29 in the WIFP, there was also an ingestion of inorganic particles, i.e. forming a partly detritus-based diet, in WFP. Large quantities of resting eggs in the gut content are commonly found in fish larvae, because these poorly digested structures are usually ingested due to their small size (Table 4).

Gut content indicated that tambaqui larvae ingested the same items in treatments $\left(\mathrm{WFP}_{\mathrm{rs}}=0.604\right.$; $\mathrm{WIFP}_{\mathrm{rs}}=0.598 ; \mathrm{P}>0.01$ ) between days 8 to 29 . However, from day 29 to day 43 tambaqui larvae showed greater ingestion than during the former period (WFP $-\mathrm{U}=33 \mathrm{~V}^{9-9}$; WIFP $-\mathrm{U}=36>\mathrm{V}^{8-9} ; \mathrm{P}<0.05$ ). Moreover tambaqui larvae fed more intensively in WIFP than in WFP $(\mathrm{P}<0.05)$.

\subsection{Growth}

Weight and length growth rate of the larvae did not differ in the treatments, the alometric equations obtained in the treatments with and without macrophyte fertilizer, respectively, being $\mathrm{y}=0.0187 \times 2.8244$ and $\mathrm{y}=0.0227 \times 2.7668$.

There was an increase in growth rate in weight and length from 36 to 43-days-old, which resulted in a decrease in condition factor values. Condition factor,
$\mathrm{a}=\mathrm{K}=0.0187$ and $\mathrm{a}=\mathrm{K}=0.0227$, showed that the larvae behaved similarly in WFP and WIFP treatments (Table 5).

\section{Discussion}

Tambaqui larvae did not select $(\mathrm{P}>0.01)$ phytoplanktonic organisms in two treatments. The phytoplankton found in gut contents was mostly Chlorophyta (WIFP) and Cyanobacteria (WFP), especially at the start of tambaqui larvae development.

Das and Jana (2003) reported that enhanced nutrient uptake by Eichhornia crassipes induced a stable environment and favoured the development of grazing food chain leading to fish growth.

Sahu et al. (2002), showed that better planktonic growth and higher productivity have been reported by the application of water hyacinth fertilizer when compared to the application of inorganic fertilizer in ponds.

WFP presented a higher abundance of planktonics organisms, like Rotifera. This fact has positive results since, during the initial stages of development, fish larvae tend to ingest small easily-captured zooplankton.

According Roa et al. (1998), rotifers were the most important dietary items for planktonivorous fish ( $\leq 50 \mathrm{~mm}$ ) and comprised 27.4 to $43.8 \%$ of fish diets.

Tambaqui larvae preferred Copepoda, mainly Argyrodiaptomus furcatus nauplii, during the experiment. Tambaqui larvae of 8-43 days-old selected A. furcatus nauplii due to the zigzag movement of copepod nauplii, with subsequent pauses for floating, small size, and high nutritional value (Sipaúba-Tavares et al., 2001).

Since Copepoda constitute a major part of the diet of the fish larvae in the natural pelagic food chain, it is generally believed that Copepoda may meet the nutritional requirements of fish larvae (Evjemo et al., 2003).

There was a direct relationship between copepodid and nauplii availability in the pond environment and their presence in the gut contents. The small size of these organisms also contributed to their high consumption by larvae (Sipaúba-Tavares and Braga, 1999; SipaúbaTavares et al., 2001).

High density of nauplii and copepodid may be related to the preference for high energy levels and greater alimentary range (Ronnastad et al., 1999).

The presence of Copepoda-Cyclopoida, Thermocyclops decipiens in treatment WFP may be due to the fact that these organisms are able to consume Cyanobacteria as a feeding source (Talamoni and Okano, 1997).

Protozoa such as Arcella discoides and Difflugia oblonga, and Haparticoida, typical of pond bottom fauna, were found in the gut contents of tambaqui larvae from day 29. Inorganic particles were also found, i.e. forming a partly detritus-based diet.

The transition of tambaqui larvae to new food sources after day 29 was related to instantaneous growth rate. This shift in feeding preferences has also been attributed to the consumption of other food items such as insects, 
Table 3. Abundance of phytoplanktonic organisms found in gut contents of the tambaqui larvae (Colossoma macropomum) in fishponds with (WFP) and without (WIFP) water hyacinth fertilizer.

\begin{tabular}{|c|c|c|c|c|c|c|c|c|c|c|c|c|}
\hline \multirow[t]{2}{*}{ Taxon } & \multicolumn{6}{|c|}{$\begin{array}{c}\text { WFP } \\
\text { AGE (days) }\end{array}$} & \multicolumn{6}{|c|}{$\begin{array}{c}\text { WIFP } \\
\text { AGE (days) }\end{array}$} \\
\hline & 8 & 15 & 22 & 29 & 36 & 43 & 8 & 15 & 22 & 29 & 36 & 43 \\
\hline \multicolumn{13}{|l|}{ CHLOROPHYTA } \\
\hline Actinastrum sp. & 4 & 6 & 0 & 3 & 0 & 6 & 2 & 6 & 5 & 4 & 4 & 0 \\
\hline Alaucosira italica & 0 & 4 & 0 & 0 & 0 & 0 & 0 & 0 & 0 & 0 & 0 & 0 \\
\hline Ankistrodesmus falcatus & 38 & 5 & 0 & 3 & 0 & 0 & 4 & 3 & 1 & 3 & 0 & 24 \\
\hline Ankistrodesmus gracilis & 2 & 5 & 6 & 14 & 2 & 5 & 5 & 2 & 1 & 19 & 14 & 456 \\
\hline Asterococcus planctonicus & 40 & 47 & 16 & 64 & 134 & 100 & 100 & 49 & 58 & 0 & 38 & 64 \\
\hline Chlorella vulgaris & 148 & 237 & 250 & 301 & 134 & 568 & 160 & 97 & 194 & 0 & 257 & 128 \\
\hline Crucigenia sp. & 0 & 0 & 0 & 0 & 0 & 0 & 0 & 0 & 0 & 1 & 0 & 0 \\
\hline Dimorphococcus lunaris & 10 & 10 & 7 & 5 & 0 & 4 & 17 & 8 & 9 & 20 & 4 & 5 \\
\hline Gloeocystis sp. & 0 & 10 & 3 & 0 & 4 & 23 & 3 & 0 & 0 & 4 & 1 & 6 \\
\hline Golenkinia sp. & 0 & 0 & 0 & 0 & 0 & 0 & 1 & 0 & 0 & 0 & 0 & 0 \\
\hline Kirchneriella lunaris & 2 & 2 & 0 & 2 & 0 & 1 & 6 & 1 & 4 & 14 & 2 & 0 \\
\hline Mougeotia sp. & 0 & 18 & 0 & 0 & 0 & 18 & 0 & 0 & 0 & 0 & 0 & 0 \\
\hline Oedogonium sp. & 9 & 7 & 6 & 5 & 6 & 0 & 0 & 6 & 6 & 3 & 0 & 19 \\
\hline Oocystis sp. & 62 & 125 & 286 & 135 & 736 & 642 & 24 & 21 & 116 & 130 & 504 & 60 \\
\hline Oocystis lacustris & 0 & 0 & 0 & 0 & 0 & 0 & 0 & 0 & 0 & 0 & 0 & 2 \\
\hline Pandorina sp. & 0 & 0 & 0 & 0 & 0 & 0 & 0 & 6 & 1 & 4 & 0 & 0 \\
\hline Pediastrum boryanum & 0 & 2 & 0 & 0 & 1 & 0 & 0 & 0 & 0 & 2 & 1 & 1 \\
\hline Pediastrum duplex & 8 & 5 & 6 & 6 & 5 & 9 & 15 & 14 & 12 & 23 & 12 & 0 \\
\hline Planktosphaeria sp. & 1 & 0 & 2 & 8 & 5 & 0 & 0 & 0 & 4 & 1 & 1 & 2 \\
\hline Scenedesmus acuminatus & 2 & 2 & 0 & 1 & 1 & 2 & 1 & 2 & 1 & 3 & 0 & 14 \\
\hline Scenedesmus bijugus & 14 & 23 & 15 & 9 & 58 & 63 & 22 & 14 & 19 & 103 & 53 & 2315 \\
\hline Scenedesmus quadricauda & 28 & 13 & 15 & 15 & 41 & 21 & 30 & 24 & 38 & 147 & 49 & 153 \\
\hline Selenastrum gracilis & 10 & 8 & 9 & 8 & 2 & 5 & 16 & 15 & 10 & 8 & 12 & 21 \\
\hline Sphaerocystis schroeteri & 0 & 0 & 0 & 1,170 & 4 & 0 & 0 & 0 & 0 & 0 & 0 & 0 \\
\hline Staurastrum sp. & 2 & 1 & 0 & 1 & 0 & 0 & 1 & 0 & 2 & 2 & 1 & 9 \\
\hline Tetradesmus sp. & 5 & 1 & 5 & 25 & 5 & 4 & 6 & 6 & 3 & 10 & 3 & 0 \\
\hline Tetraedron trigonum & 1 & 1 & 1 & 3 & 1 & 1 & 0 & 0 & 1 & 4 & 2 & 2 \\
\hline Tetrallantos $\mathrm{sp}$ & 2 & 3 & 0 & 2 & 0 & 1 & 0 & 0 & 1 & 6 & 2 & 1 \\
\hline \multicolumn{13}{|l|}{ CHRYSOPHYTA } \\
\hline Botryococcus sp. & 3 & 0 & 0 & 0 & 1 & 0 & 5 & 2 & 1 & 7 & 2 & 3 \\
\hline Centritactus sp. & 0 & 1 & 0 & 0 & 0 & 0 & 1 & 0 & 3 & 1 & 1 & 0 \\
\hline Eunotia sp. & 7 & 8 & 0 & 3 & 15 & 2 & 7 & 5 & 9 & 14 & 5 & 19 \\
\hline Fragilaria sp. & 3 & 11 & 1 & 1 & 17 & 25 & 1 & 1 & 5 & 17 & 36 & 11 \\
\hline Gomphonema sp. & 0 & 0 & 0 & 0 & 4 & 1 & 0 & 0 & 2 & 1 & 5 & 6 \\
\hline Navícula sp. & 4 & 11 & 4 & 18 & 92 & 61 & 5 & 6 & 14 & 45 & 62 & 0 \\
\hline Nitzchia sp. & 0 & 1 & 0 & 0 & 3 & 0 & 2 & 0 & 0 & 1 & 0 & 0 \\
\hline Pinnularia sp. & 1 & 0 & 1 & 1 & 3 & 0 & 0 & 0 & 0 & 1 & 0 & 0 \\
\hline Surirella sp. & 10 & 44 & 1 & 19 & 138 & 177 & 4 & 5 & 85 & 161 & 327 & 233 \\
\hline Synura sp. & 1 & 0 & 1 & 1 & 1 & 2 & 1 & 1 & 0 & 0 & 0 & 0 \\
\hline \multicolumn{13}{|l|}{ CYANOPHYTA } \\
\hline Anabaena sp. & 30 & 0 & 46 & 0 & 0 & 35 & 0 & 0 & 10 & 0 & 0 & 15 \\
\hline Merismopoedia sp. & 2 & 0 & 0 & 2 & 3 & 2 & 1 & 1 & 2 & 9 & 0 & 2 \\
\hline Microcystis sp. & 217 & 311 & 193 & 248 & 120 & 112 & 312 & 275 & 351 & 0 & 213 & 264 \\
\hline \multicolumn{13}{|l|}{ EUGLENOPHYTA } \\
\hline Phacus sp. & 1 & 1 & 0 & 1 & 1 & 0 & 3 & 0 & 3 & 1 & 3 & 2 \\
\hline Trachelomonas sp. & 152 & 347 & 114 & 138 & 419 & 91 & 286 & 201 & 270 & 0 & 136 & 141 \\
\hline
\end{tabular}


Table 4. Abundance of zooplanktonic organisms found in gut contents of the tambaqui larvae (Colossoma macropomum) in fishponds with (WFP) and without (WIFP) water hyacinth fertilizer.

\begin{tabular}{|c|c|c|c|c|c|c|c|c|c|c|c|c|}
\hline \multirow[t]{2}{*}{ Taxon } & \multicolumn{6}{|c|}{$\begin{array}{c}\text { WFP } \\
\text { AGE (days) }\end{array}$} & \multicolumn{6}{|c|}{$\begin{array}{c}\text { WIFP } \\
\text { AGE (days) }\end{array}$} \\
\hline & 8 & 15 & 22 & 29 & 36 & 43 & 8 & 15 & 22 & 29 & 36 & 43 \\
\hline \multicolumn{13}{|l|}{ ROTIFERA } \\
\hline Ascomorpha sp. & 0 & 0 & 0 & 0 & 0 & 0 & 0 & 1 & 0 & 0 & 0 & 0 \\
\hline Asplanchna sp. & 0 & 0 & 0 & 0 & 0 & 0 & 0 & 1 & 0 & 0 & 0 & 0 \\
\hline Asplancnopsis girardi & 0 & 0 & 0 & 0 & 0 & 0 & 0 & 0 & 1 & 0 & 0 & 0 \\
\hline Brachionus calyciflorus & 0 & 0 & 0 & 0 & 0 & 0 & 0 & 0 & 0 & 0 & 0 & 4 \\
\hline Brachionus caudatus & 0 & 0 & 0 & 0 & 0 & 0 & 0 & 0 & 0 & 0 & 1 & 0 \\
\hline Brachionus dolabratus & 0 & 0 & 0 & 0 & 0 & 0 & 1 & 0 & 1 & 0 & 0 & 0 \\
\hline Brachionus patulus & 0 & 1 & 2 & 0 & 0 & 0 & 7 & 0 & 0 & 0 & 0 & 0 \\
\hline B. quadridentatus mirabilis & 10 & 0 & 0 & 0 & 0 & 2 & 0 & 0 & 0 & 0 & 0 & 15 \\
\hline Cephalodella rheimani & 0 & 0 & 0 & 0 & 0 & 0 & 0 & 0 & 0 & 1 & 0 & 0 \\
\hline Colurella dicentra & 0 & 0 & 0 & 0 & 0 & 0 & 0 & 1 & 0 & 0 & 0 & 0 \\
\hline Colurella trilobata & 0 & 0 & 0 & 0 & 0 & 0 & 0 & 0 & 3 & 0 & 0 & 0 \\
\hline Epiphanes macrourus & 0 & 0 & 0 & 0 & 0 & 0 & 0 & 0 & 2 & 0 & 0 & 0 \\
\hline Euchlanis sp. & 0 & 1 & 0 & 0 & 0 & 0 & 0 & 0 & 1 & 0 & 0 & 0 \\
\hline Euchlanis meneta & 0 & 0 & 0 & 0 & 0 & 0 & 0 & 0 & 0 & 0 & 0 & 1 \\
\hline Hexarthra.Sp. & 0 & 0 & 0 & 17 & 0 & 0 & 0 & 0 & 15 & 0 & 0 & 0 \\
\hline Ilyocryptus spinifer & 0 & 4 & 0 & 0 & 4 & 1 & 0 & 0 & 0 & 5 & 4 & 0 \\
\hline Keratella cochlearis & 0 & 0 & 2 & 23 & 1 & 2 & 0 & 3 & 5 & 3 & 1 & 4 \\
\hline Keratella lenzi & 2 & 3 & 2 & 0 & 0 & 0 & 0 & 0 & 0 & 0 & 0 & 0 \\
\hline Lecane monostyla & 0 & 1 & 0 & 1 & 0 & 0 & 0 & 4 & 21 & 2 & 15 & 31 \\
\hline Lecane signifera & 0 & 0 & 0 & 0 & 0 & 0 & 0 & 0 & 0 & 0 & 0 & 1 \\
\hline Lepadella custata & 0 & 0 & 0 & 0 & 0 & 0 & 0 & 0 & 1 & 0 & 0 & 0 \\
\hline Lepadella ovalis & 0 & 0 & 0 & 0 & 0 & 0 & 0 & 1 & 0 & 0 & 0 & 3 \\
\hline Lepadella patela & 0 & 0 & 0 & 0 & 0 & 0 & 0 & 0 & 1 & 0 & 0 & 0 \\
\hline Pompholyx complanata & 0 & 4 & 0 & 1 & 0 & 3 & 0 & 0 & 0 & 1 & 0 & 4 \\
\hline Pompholyx trilobata & 0 & 0 & 0 & 0 & 0 & 0 & 0 & 5 & 0 & 0 & 0 & 0 \\
\hline Proales auptopus & 0 & 0 & 0 & 0 & 0 & 0 & 0 & 0 & 2 & 0 & 0 & 0 \\
\hline Proales doliaris & 0 & 0 & 0 & 2 & 0 & 0 & 1 & 0 & 11 & 0 & 0 & 1 \\
\hline Proales globolifera & 0 & 0 & 0 & 2 & 0 & 0 & 0 & 0 & 90 & 0 & 0 & 0 \\
\hline Ptygura sp. & 0 & 0 & 0 & 0 & 0 & 0 & 0 & 1 & 0 & 1 & 0 & 0 \\
\hline Testudinella ohlei & 0 & 0 & 0 & 0 & 0 & 0 & 0 & 14 & 6 & 0 & 0 & 0 \\
\hline Trichocerca bicutata & 0 & 0 & 1 & 2 & 0 & 0 & 1 & 0 & 1 & 2 & 0 & 0 \\
\hline Vanoyella globosa & 0 & 0 & 0 & 0 & 0 & 0 & 0 & 1 & 0 & 0 & 0 & 0 \\
\hline \multicolumn{13}{|l|}{ CLADOCERA } \\
\hline Daphnia gessneri & 0 & 0 & 0 & 0 & 0 & 0 & 0 & 0 & 1 & 1 & 0 & 0 \\
\hline Diaphanosoma birgei & 0 & 0 & 0 & 0 & 1 & 0 & 0 & 0 & 0 & 1 & 0 & 0 \\
\hline Echinischia paulineis & 0 & 2 & 0 & 0 & 0 & 4 & 0 & 0 & 0 & 0 & 0 & 0 \\
\hline Moina micrura & 0 & 2 & 0 & 0 & 2 & 0 & 0 & 0 & 0 & 4 & 6 & 0 \\
\hline \multicolumn{13}{|l|}{ COPEPODA } \\
\hline \multicolumn{13}{|l|}{ Argyrodiaptomus furcatus } \\
\hline nauplii & 3 & 4 & 0 & 0 & 1 & 6 & 1 & 5 & 112 & 0 & 3 & 0 \\
\hline copepodid & 5 & 5 & 0 & 0 & 2 & 7 & 0 & 1 & 6 & 2 & 0 & 1 \\
\hline \multicolumn{13}{|l|}{ Thermocyclops decipiens } \\
\hline copepodid & 0 & 9 & 0 & 0 & 0 & 1 & 1 & 0 & 0 & 1 & 5 & 0 \\
\hline \multicolumn{13}{|l|}{ Harpacticoida } \\
\hline adult & 0 & 0 & 0 & 1 & 0 & 1 & 0 & 0 & 0 & 0 & 0 & 0 \\
\hline
\end{tabular}


Table 4. Continued...

\begin{tabular}{|c|c|c|c|c|c|c|c|c|c|c|c|c|}
\hline \multirow[t]{2}{*}{ Taxon } & \multicolumn{6}{|c|}{$\begin{array}{c}\text { WFP } \\
\text { AGE (days) }\end{array}$} & \multicolumn{6}{|c|}{$\begin{array}{c}\text { WIFP } \\
\text { AGE (days) }\end{array}$} \\
\hline & 8 & 15 & 22 & 29 & 36 & 43 & 8 & 15 & 22 & 29 & 36 & 43 \\
\hline \multicolumn{13}{|l|}{ PROTOZOA } \\
\hline Arcella discoides & 0 & 0 & 0 & 15 & 4 & 3 & 0 & 0 & 0 & 12 & 1 & 0 \\
\hline Difflugia sp. & 1 & 0 & 0 & 0 & 0 & 0 & 0 & 0 & 0 & 0 & 0 & 0 \\
\hline Difflugia oblonga & 0 & 0 & 0 & 15 & 4 & 3 & 0 & 0 & 0 & 0 & 1 & 9 \\
\hline \multicolumn{13}{|l|}{ OTHERS } \\
\hline Chaoborus sp. & 0 & 0 & 0 & 0 & 0 & 0 & 0 & 0 & 0 & 0 & 4 & 1 \\
\hline Insecta & 0 & 2 & 0 & 1 & 5 & 2 & 0 & 0 & 0 & 10 & 0 & 61 \\
\hline Ostracoda & 0 & 12 & 0 & 1 & 14 & 9 & 0 & 0 & 0 & 3 & 33 & 0 \\
\hline Resting eggs & 0 & 2 & 1 & 7 & 4 & 47 & 8 & 1 & 4 & 6 & 1 & 165 \\
\hline Inorganic particles & 0 & 0 & 0 & 0 & 5 & 15 & 0 & 0 & 0 & 0 & 0 & 0 \\
\hline
\end{tabular}

Table 5. Mean weight (mg), length (mm) and instantaneous growth rate $(\mathrm{G})$ of the tambaqui larvae (Colossoma macropomum) in treatments with (WFP) and without (WIFP) water hyacinth fertilizer.

\begin{tabular}{|c|c|c|c|c|c|c|c|c|}
\hline \multirow[b]{2}{*}{$\begin{array}{c}\text { AGE } \\
\text { (days) }\end{array}$} & \multicolumn{4}{|c|}{ WFP } & \multicolumn{4}{|c|}{ WIFP } \\
\hline & $\begin{array}{l}\text { Weight } \\
\text { (mg) }\end{array}$ & $\begin{array}{c}\mathbf{G} \\
\left(\mathrm{mg.day}^{-1}\right)\end{array}$ & $\begin{array}{c}\text { Length } \\
(\mathbf{m m})\end{array}$ & $\begin{array}{c}\mathbf{G} \\
\left(\text { mg.day }^{-1}\right)\end{array}$ & $\begin{array}{l}\text { Weight } \\
\text { (mg) }\end{array}$ & $\begin{array}{c}\mathbf{G} \\
\left(\mathbf{m g . d a y}^{-1}\right)\end{array}$ & $\begin{array}{l}\text { Length } \\
(\mathrm{mm})\end{array}$ & $\begin{array}{c}\mathbf{G} \\
\left(\mathrm{mg.day}^{-1}\right)\end{array}$ \\
\hline \multirow[t]{2}{*}{8} & 14.8 & - & 8.0 & - & 13.2 & - & 7.5 & - \\
\hline & - & 0.040 & - & 0.039 & - & 0.007 & - & 0.009 \\
\hline \multirow[t]{2}{*}{15} & 19.6 & - & 10.5 & - & 13.9 & - & 8.0 & - \\
\hline & - & 0.002 & - & 0.007 & - & 0.043 & - & 0.032 \\
\hline \multirow[t]{2}{*}{22} & 19.9 & - & 11.0 & - & 18.8 & - & 10.0 & - \\
\hline & - & 0.018 & - & 0.012 & - & 0.022 & - & 0.026 \\
\hline \multirow[t]{2}{*}{29} & 22.5 & - & 12.0 & - & 22.0 & - & 12.0 & - \\
\hline & - & 0.234 & - & 0.066 & - & 0.253 & - & 0.058 \\
\hline \multirow[t]{2}{*}{36} & 115.6 & - & 19.0 & - & 129.6 & - & 18.0 & - \\
\hline & - & 0.063 & - & 0.011 & - & 0.015 & - & 0.00 \\
\hline 43 & 180.2 & - & 20.5 & - & 144.0 & - & 18.0 & - \\
\hline
\end{tabular}

Chaoborus sp and a high percentage of Cladocera resting eggs in the gut content.

Since fish larvae generally ingest small particles, large quantities of resting eggs in gut contents have been consequently reported (Sipaúba-Tavares et al., 2001).

In the case of the tambaqui, a tropical freshwater fish from the Amazon region, little is known about the feeding behavior of its larvae as they migrate in the Amazon river to streams during their development. In streams, zooplankton is the most ingested item for 1-2 cm-long larvae; when they reach $1.5 \mathrm{~cm}$ they are no longer larvae and ingest such food items as wild rice (Araújo-Lima and Goulding, 1998).

In the current study the changes reported in the feeding behavior coincided with changes observed in the larvae development and growth. Changes in development may be due to the ontogenic development of the larvae.

\subsection{Comments and Suggestions}

The current investigation indicated the usefulness of water hyacinth as a low-cost organic fertilizer in fishponds. Better planktonic growth was recorded by the application of organic fertilizer to increase plankton population. The dominance of the Cyanobacteria in WFP treatment is not well suited for larvae fishpond, since toxins, which interfere with flesh quality or even larvae survival, may be produced. However, WFP treatment produced significant density of $A$. furcatus nauplii with their high nutritional value and Protozoa (high phosphorus reservoirs). High abundance of Rotifera, initial sources of food to fish larvae was also reported in WFP. In the case of tambaqui larvae, artificial feed introduced after day 29 is thus recommended when the larvae shift their feeding preferences. More research should be done to evaluate the effect of the use of water hyacinths as a fertilizer for a satisfactory response to Cyanobacteria. However, water hyacinth fertilizer is quite cheap and easily obtainable. Consequently the farmer can conveniently use it in ponds for enhancing fish yield.

Acknowledgments - The authors wish to thank the Fundação de Amparo à Pesquisa do Estado de São Paulo [São Paulo State 
Foundation for Research Support - FAPESP] for its financial support and the CEMIG for supply of larvae.

\section{References}

ARAÚJO-LIMA, C. and GOULDING, L., 1998. Os frutos do tambaqui. Ecologia, Conservação e Cultivo na Amazônia. Sociedade Civil Mamirauá, MCT-CNPq.

DAS, SS. and JANA, BB., 2003. Fish-macrophyte association as a low-cost strategy for wastewater reclamation. Ecological Engineering, vol. 21, p. 21-41.

-, 2004. Distribution pattern of ambient cadmium in wetland ponds distributed along an industrial complex. Chemosphere, vol. 55 , p. 175-185.

EL-SAYED, AF., 2003. Effects of fermentation methods on the nutritive value of water hyacinth for Nile tilapia Oreochromis niloticus (L.) fingerlings. Aquaculture, vol. 218, p. 471-478.

EVJEMO, JO., REITAN, KI. and OLSEN, Y., 2003. Copepods as live food organisms in the larval rearing of halibut larvae (Hippoglossus hippoglossus L.) with special emphasis on nutritional value. Aquaculture, vol. 227, p. 191-210.

JORGENSEN, SE., 1994. A general model of nitrogen removal by wetlands. Amsterdam, p. 575-583. In MITSCH, WJ. (ed.), Global Wetlands: Old World and New. Amsterdam.

POLPRASERT, C. and KHATIWADA, NR., 1998. An integrated kinetic model for water hyacinth ponds used for wastewater treatment. Water Res., vol. 32, p. 179-185.

RICKER, WE., 1979. Growth rates and models. New York p. 677-743. In HOAR, WS., RONDALL, DJ., BRETT, JR. (eds.). Fish Phyisology: Bioenergetics and Growths. New York.

ROA, EZ., PALACIOS-CÁCERE, M. and PARDO, MJ., 1998. Zooplankton as dietary components of small fish species in a flooded savana of Venezuela. Verein. Limnology. vol. 2, no. 6, p. $1359-1363$.

RONNASTAD, I., THORSEN, A. and FINN, RN., 1999. Fish larvae nutrition: a review of recent advances in the roles of amino acids. Aquaculture. vol. 177, no. 1-4, p. 201-216.

SÁ, MFP de, 1989. Efeito da adubação orgânica sobre o crescimento de Cyprinus carpio, Prochilodus cearensis $e$ Colossoma macropomum em experimento de policultivo. Dissertação de Mestrado, Universidade Federal de São Carlos, São Carlos, 162p.

SAHA, SS. and JANA, BB., 2002. Determination of water hyacinth biomass/water area ratio for effective reclamation in simulated models of wastewater at two nutrient levels. Int. J.Environ.Stud., vol. 59, p. 623-634.

SAHU, AK., SAHOO, SK. and GIRI, SS., 2002. Efficacy of water hyacinth compost in nursery ponds for larval rearing of Indian major carp, Labeo rohita. Bioresource Technology, vol. 85, p. 309-311.

SIEGEL, S., 1975. Estatística não paramétrica. Editora Mcgraw-Hill do Brasil Ltda, São Paulo, 137p.

SIPAÚBA-TAVARES, LH. and BRAGA, FM. de S., 1999. Study on feeding habits of Piaractus mesopotamicus (pacu) larvae in fishponds. ICLARM Aquabyt, vol. 22, no. 1, p. 24-30.

SIPAÚBA-TAVARES, LH., BACHION, MA. and BRAGA, FM. de S., 2001. Effects of food quality on growth and biochemical composition of a calanoid copepod, Argyrodiaptomus furcatus, and its importance as a natural food source for larvae of two tropical fishes. Hydrobiologia, vol. 453/453, p. 393-401.

TALAMONI, JLB. and OKANO, WY., 1997. Limnological characterization and plankton community structure in aquatic systems of different trophic state. Verh. Internat. Verein. Limnol., vol. 26, p. 629-636. 